\title{
HIGHER EARNINGS IN LARGE FIRMS? EMPLOYER SIZE-WAGE RELATION IN THE CZECH REPUBLIC ${ }^{1}$
}

\section{Diana Bílková*}

\begin{abstract}
Current research is primarily focused on the wage issue in the Czech Republic in relation to the size of the enterprise. This paper examines the development of wage rates in companies classified by the number of employees from the 2008 economic crisis onwards. Since the analysis and estimation of current trends in wage differentiation based exclusively on average and median wages are insufficient, moving from level characteristics to the entire frequency distribution appears justifiable. Wage distribution models based on three-parameter lognormal curves and broken down by the number of company employees were constructed to trace wage developments from the onset of the recession; the starting points of the curves represent the minimum wage in the respective year. The remaining two parameters were estimated utilising the maximum likelihood method. Having applied the curves, the proportions of employees with wages not exceeding a certain threshold were calculated. With the gross monthly wage dependence on the company size having been verified via one-way analysis of variance, the research has confirmed that large foreign firms provide the highest possible paying jobs. The average wage difference between the very large and the smallest organizations was calculated to reach almost 15,500 CZK; average wages in the latter firms representing only $55 \%$ of those earned in the former companies. As for the median wage, the difference amounts to almost 14,000 CZK. It has also been proven that an estimated $91.40 \%$ of employees in the smallest firms do not achieve the average wage, whereas in large and very large companies this share is estimated at $47.10 \%$ and $51.56 \%$, respectively.
\end{abstract}

Keywords: wage development, company size, Gini coefficient of diversification, wage distribution models, three-parameter lognormal curves, maximum likelihood method

JEL Classification: J31, E24, D31, C46, C51

\section{Introduction}

The paper raises the question of whether, and if so, to what extent the size of a company affects the wage level of its employees. Six categories of firms in terms of the number of employees have been identified (those with less than 10; between 10 and 49; 50 and 249; 250 and 999; 1,000 and 4,999; and companies with 5,000 or more staff, respectively),

1 This paper was subsidized by the institutional support funds for the long-term conceptual advancement of science and research, number IP400040, at the Faculty of Informatics and Statistics, University of Economics, Prague, Czech Republic.

* University of Economics, Prague, Faculty of Informatics and Statistics (diana.bilkova@vse.cz). 
encompassing both business and non-business entities in the Czech Republic. The research period spans the years 2009 to 2016. The 2008 global downturn impacted on the Czech economy, which suffered a 4.8\% real GDP decline in 2009.

The annual data generated for analysis comes from the official website of the Czech Statistical Office (CSO). The data is in the form of interval frequency distribution with uneven, wide-open intervals and the key variable examined being the gross (nominal) monthly wage. As for the CSO data, both wages, paid to an employee for work done in the private business - sphere, and salaries, earned in the budget - state, public, non-business - sector, are covered by the term "wage". There are nominal wages for full-time staff and the number of employees converted to the equivalent full-time workload. The monitored period, which covers the entire business cycle, the range of effects (e.g. crisis impacts, enforced shorter working hours, layoffs of low-skilled workers, sickness absences) is potentially broad. However, long-term CSO data was not available. The data was processed using SAS and Statgraphics statistical packages and a Microsoft Excel spreadsheet.

An exploration of the wage dependence on company size in terms of the number of employees is the main objective of the current research. Since the analysis of current development in wage differentiation grounded solely on average and median wages has proved unsatisfactory then abandoning the level characteristics and stressing the entire frequency distribution appears reasonable. Models demonstrating wage distribution trends in terms of company size are constructed. These are based on three-parameter lognormal curves with their beginnings representing the minimum wage in the respective years. The other two parameters are estimated by the maximum likelihood method. Using the lognormal curves obtained, the proportions of employees whose gross monthly wage reaches a certain maximum (between 15,000 and 120,000 CZK) were calculated. The dependence of the wage level on company size is investigated performing a one-way analysis of variance.

Based on this research, it can be claimed that the wage level increases with the establishment size with the employees of the largest foreign companies receiving the highest wages in the Czech Republic.

\section{Literature Review}

When job seeking, applicants' decisions may also be affected by the size of a potential employer. Despite small firms possessing some advantages (such as the natural group cohesion of staff or thinner management bureaucracies), the remuneration package for employees remains the problem. Therefore, the relationship between the wage premium paid to employees and the size of the enterprise has become the focus of investigation for many authors. Only some of these are mentioned here.

For example, Brian and Reilly (1993) present their estimates of the employer sizewage gap for Britain. Using an ordered probit model, selectivity-corrected wage equations are estimated for three company size categories. Having compared companies with more than 500 workers to those with less than 100, the authors calculated that the wage gap would rise to $17 \%$. Reilly (1995) examines the establishment size effect on earnings via a cross-sectional study of 607 employees of 60 private companies applying the 1979 data. He suggests that when a dummy variable on computer access in an organisation is used as a regressor, the company size variable is insignificant. Brown and Medoff (1989) consider the factors that shape the positive relationship between employer size and wages 
(a large employer, higher-skilled workers, inferior working conditions, a wage increase forestalling unionisation, ability to pay high wages, smaller pools of applicants in relation to vacancies, reduced employee monitoring capability), confirming a significant wage premium for employees working for large firms. Kruse (1992) explores two hypothetical effects of organisation size on wages using the 1980 job survey data. The author confirms a major dependency for both medium-sized and large companies with the employeereported supervision frequency only - negatively - affecting pay. A common explanation is that large companies possess at least one of the following characteristics: [1] advanced workforce capabilities [undetectable by standard capability measurement methods], [2] the major threat posed by trade unions, high wages dissuading employees to join them, [3] great market power, allowing for rent sharing with staff, and [4] bad working conditions generating high compensation wage differentials (which may be also caused by shirking and turnover costs, bad hires, or work ethic reasons).

Barron, Black and Loewenstein (1987) use a unique data set to demonstrate empirical relationships between wage levels and the firm's size, recruitment strategies, training programmes and capital investments if large employers report high monitoring costs (due to costly job applicant screening procedures, the hire rate, training and retaining new employees, and the provision of a compensation package), and the capital investment rate being considered to minimise overall production costs. Hartog, Opstal, and Teulings (1997) argue that there may be a systematic relationship between the magnitude of noncompetitive wage differentials and the degree of centralisation in bargaining over employment contracts. Velenchik (1997) uses matched employer-employee data from a survey of 201 manufacturing firms with 1609 workers conducted in Zimbabwe in 1993. The results indicate that there is a substantial premium associated with employment in large firms that cannot be explained by the differences in workforce quality and job characteristics or reduced by controlling for unionisation, minimum wages or other forms of government intervention. Schmidt and Zimmermann (1991) attempt to distinguish company size from other wage determinants, drawing from a rich database for West Germany and highlighting the persistence of the size premium. Dunne and Schmitz (1995) show that enterprises embracing state-of-the-art technologies pay the highest wages and employ the largest fraction of non-production workers (generally regarded as more skilled than production ones), standard wage regressions of technology classification variables reducing the size-wage differences by $60 \%$ for some company size categories. Mellow (1982) suggests - referring to numerous empirical studies - that large enterprises are associated with the ability to pay higher wages (to compensate employees for possible unfavourable working conditions and offset turnover and monitoring costs in particular). Allemand, Plasman and Rycx (2007) examine the magnitude and determinants of the establishment size-wage premium in five European countries utilising a unique harmonised matched employer-employee database (the 1995 European Structure of Earnings Survey). They conclude that there is a substantial wage premium for workers in large firms. Brunelloa and Colussib (1998) find that empirical estimates are rather sensitive to the assumptions made in the modelling of the allocation of workers to company sizes with the estimated unconditional firm-size average log wage differential not being noticeably different from zero. Thus, differences in returns to similar characteristics for people working in both small and large private companies are subtle and not significantly different from zero; the average log wage differential is explained by the differences in the observed individual 
characteristics and selection effects. Hollister (2004) notes that large firms pay higher wages than small ones to workers with similar characteristics. However, such an effect of establishment size on wages is not properly explained.

The current study addresses the issue of different wages paid in small and large enterprises in the Czech Republic and examines wage growth in relation to the number of employees in the company.

\section{Theory and Methodology}

Simple descriptive characteristics are applied to trace the development of the empirical distribution of the gross monthly wage since 2009 (e.g. Larson and Farber, 2015). The Gini coefficient is used to describe the diversification of the wage distribution by company size in the given period.

The essence of three-parameter lognormal curves applied in wage distribution modelling and the maximum likelihood method used for their point parameter estimation are explained in Johnson, Kotz and Balakrishnan $(1994,1995)$ with the former also being addressed by Kleiber and Kotz (2003).

The procedures and assumptions of the one-way analysis of variance (ANOVA) used in the verification of the gross monthly wage dependence on the company size are described in Glantz, Slinker and Neilands (2016). In practice, the tests confirming the assumptions of normality and the same variances are often omitted. In terms of normality, when taking large wage distribution sample sizes into account, it is to be considered whether the extreme values are not present in the groups of those of the explained variable $y$ that are at certain levels of factor $x$, and if the values close to conditional averages are more frequent than the more distant ones. If this is fulfilled, it can be assumed that the conditional distributions of the explained variable $y$ at various levels of factor $x$ are not significantly different from the normal distribution. Small deviations from the normal distribution do not usually affect the conclusions reached in the analysis of variance as the same variance assumptions mostly result from an intuitive assessment of the difference between conditional variances. If this difference is not too large for small samples and for large ones is very small, the assumption of the same variances can be considered fulfilled for all $k$ normal distributions.

The fluctuation of conditional averages of the explained variable (intergroup variability) appears to be a result of the explained variable dependence on the explanatory variable (factor $x$ ). The fluctuation of the explained variable's individual values within the given company size groups fixed by the level of the $x$ factor (intragroup variability) is considered the result of the dependence of the explained variable on other factors. The stronger the dependence of the explained variable on factor $x$, the greater the proportion of intergroup variability and, therefore, the smaller the proportion of intragroup variability in the overall variability.

\section{Results and Discussion}

As far as the size of companies is concerned, there are six basic categories ${ }^{2}-$ microenterprises (with 1-9 employees), very small firms (10-49), small (50-249), medium (250-999), large $(1,000-4,999)$ and very large ones (with 5,000 or more employees),

2 The classification of companies according to the number of staff used in tables and figures in this paper was taken from the CSO website. 
respectively. The size of the enterprise is one of the most important factors influencing the wage rate, especially for senior executives. The direct proportion applies - the larger the company, the higher the earnings.

Companies' positive attitude towards fair remuneration is increasingly common in the Czech Republic. However, the income of a Czech manager is about one third compared to that of a German manager. Moreover, firms experience a shortage of both high and low-qualified (i.e. high and low paid) employees.

Table 1 provides information on the average and median gross monthly wage according to company size in 2016. It is clear from this table that the difference between the average wage in very large and the smallest establishments reaches almost 15,500 CZK with average wages in the latter firms representing only $55 \%$ of those earned in the former companies. As for the median wage, the difference is almost $14,000 \mathrm{CZK}$; the median in micro firms, for instance, just reaching $54 \%$ of that in very large enterprises (see Table 1).

Table 1 | Average and median gross monthly wage (in CZK) by the number of employees (2016)

\begin{tabular}{|c|c|c|c|c|}
\hline \multirow{2}{*}{$\begin{array}{l}\text { Company size } \\
\text { (No. of employees) }\end{array}$} & \multicolumn{2}{|c|}{ Average wage } & \multicolumn{2}{|c|}{ Median wage } \\
\hline & $\begin{array}{l}\text { Absolute } \\
\text { amount }\end{array}$ & Percentage & $\begin{array}{l}\text { Absolute } \\
\text { amount }\end{array}$ & Percentage \\
\hline up to 10 employees & 18,475 & 10 & 15,895 & 11 \\
\hline from 10 to 49 employees & 26,760 & 15 & 23,663 & 16 \\
\hline from 50 to 249 employees & 29,696 & 17 & 25,181 & 17 \\
\hline from 250 to 999 employees & 32,755 & 19 & 27,039 & 18 \\
\hline from 1,000 to 4,999 employees & 35,180 & 20 & 29,988 & 19 \\
\hline 5,000 or more employees & 33,741 & 19 & 29,522 & 19 \\
\hline Sum & & 100 & & 100 \\
\hline
\end{tabular}

Source: Author's own research

Table 2 | Average annual increase or decrease (-) in average and median gross monthly wage (in \%)

\begin{tabular}{|c|c|c|c|c|c|c|c|}
\hline \multirow{2}{*}{ Wage } & \multirow{2}{*}{ Period } & \multicolumn{6}{|c|}{ Company size (No. of employees) } \\
\hline & & $1-9$ & $10-49$ & $50-249$ & $250-999$ & $1,000-4,999$ & $5,000+$ \\
\hline \multirow{3}{*}{$\begin{array}{l}\text { Average } \\
\text { wage }\end{array}$} & Ø 2009-2013 & -4.19 & -0.28 & 0.89 & 2.38 & 1.98 & 1.33 \\
\hline & Ø 2013-2016 & 3.39 & 3.35 & 3.51 & 3.68 & 3.35 & 2.81 \\
\hline & Ø 2009-2016 & -1.01 & 1.26 & 2.01 & 2.94 & 2.57 & 1.96 \\
\hline \multirow{3}{*}{$\begin{array}{l}\text { Median } \\
\text { wage }\end{array}$} & Ø 2009-2013 & -6.34 & 0.98 & 1.44 & 2.59 & 2.60 & 0.32 \\
\hline & $\varnothing$ 2013-2016 & 2.38 & 3.28 & 3.97 & 3.98 & 3.20 & 3.56 \\
\hline & Ø 2009-2016 & -2.70 & 1.96 & 2.52 & 3.18 & 2.85 & 1.70 \\
\hline
\end{tabular}

Source: Author's own research 
Figures 1 and 2 show the development of the average and median wage throughout the research period, indicating a sharp decline in the wage level for micro-enterprises in 2011 and 2012 and a slight decrease for very small and very large firms (median wage in the case of the latter) in 2010 and 2011, respectively. It follows from the figures that the companies in the above-mentioned sizes were particularly affected by the global economic downturn.

The values in Table 2 - representing the average annual growth rate of average and median monthly wages over the periods of the economic crisis (2009-2013), its aftermath (2013-2016) and the entire research project (2009-2016) -, are also indicative of the above conclusions. During the recession, firms with less than 10 employees reported an average annual decline of $4.19 \%$ in the average gross monthly wage with the average drop in the median wage being even more at $6.34 \%$. The average wage in companies with 10 to 49 staff decreased slightly by $0.28 \%$ a year. Negative values of the average annual growth rate of average and median gross monthly wages over the whole research period are due to the relatively high minus values during the crisis.

Table 3 provides information on the development of the absolute and relative variability of wage distributions over the research period. Absolute variability is measured by the standard deviation, indicating the quadratic average of all employees' wage deviations from their average wage. The coefficient of variation represents a feature of relative variability. After multiplying by a hundred, the variation coefficient shows the percentage share of the standard deviation of employees' wages in their average wage with values higher than $50 \%$ indicating significant heterogeneity in employee wages.

Figure 1 | Average gross monthly wage growth rate (in \%, 2009-2016)

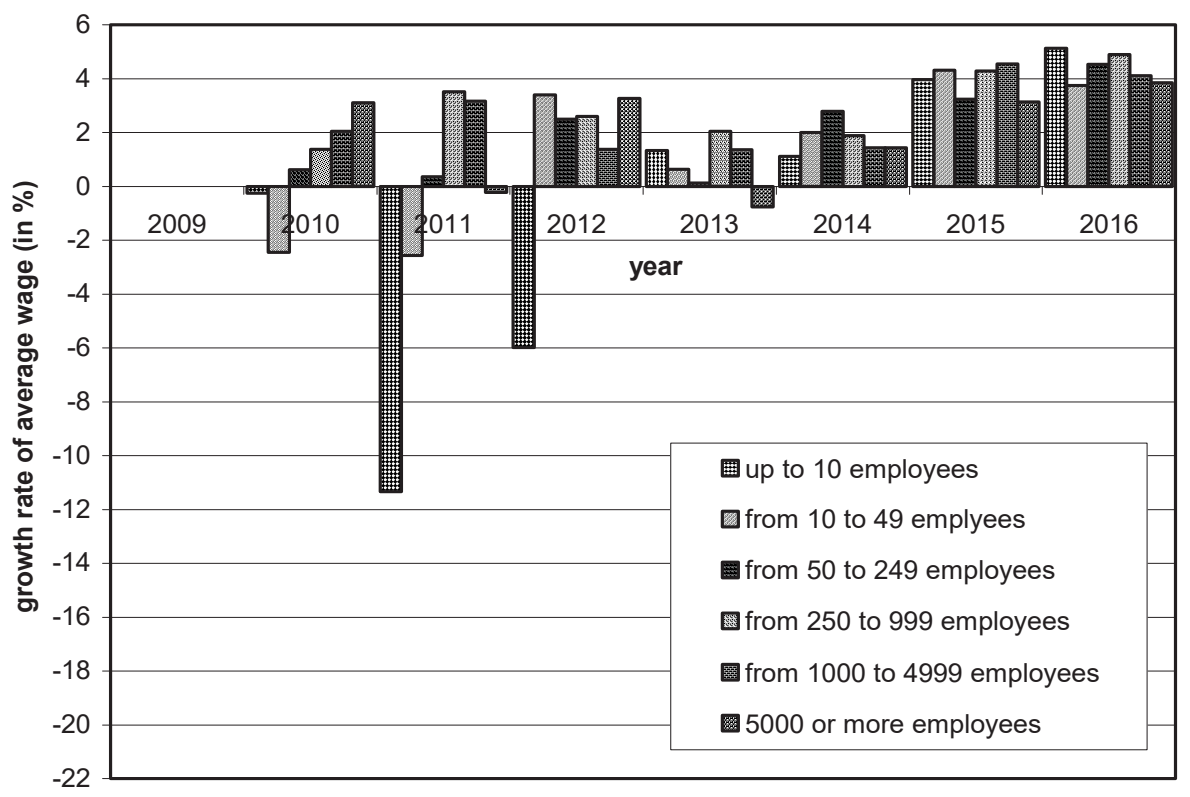

Source: Author's own research 
Table 3 also shows the development of the Gini coefficient according to company size throughout the monitored period. The more the value of the Gini coefficient approaches $0 \%$, the more egalitarian the wage distribution is, i.e. the coefficient equalling zero theoretically indicates extreme wage levelling. The closer the values of the Gini coefficient to $100 \%$, the greater the wage inequality, i.e. the coefficient equalling $100 \%$ theoretically indicates extreme diversification, the whole wage being received by one employee. However, extreme Gini coefficient values are not realistically achievable.

It is obvious from Table 3 that the wages paid in companies employing between 10 and 49 staff are the most diversified with the lowest wage diversification being recorded in the micro firms over the whole research period (except for 2011, when the consequences of the economic downturn fully impacted wage distribution in the Czech Republic).

Figures 3-8 (see the appendix) enable to assess the development of wage distributions by company size over time. Considerable differences in the shape of wage distributions between establishments of different sizes are not noticeable. The only exceptions are micro (and partly very small enterprises) paying low level and narrow variability wages that show higher positive skewness and kurtosis. This means that most employees earn low wages, which are also the least diversified among all company sizes. For all other companies, it is true that the wage level has increased since the global recession with wage distributions having low skewness and kurtosis.

Figure 2 | Median gross monthly wage growth rate (in \%, 2009-2016)

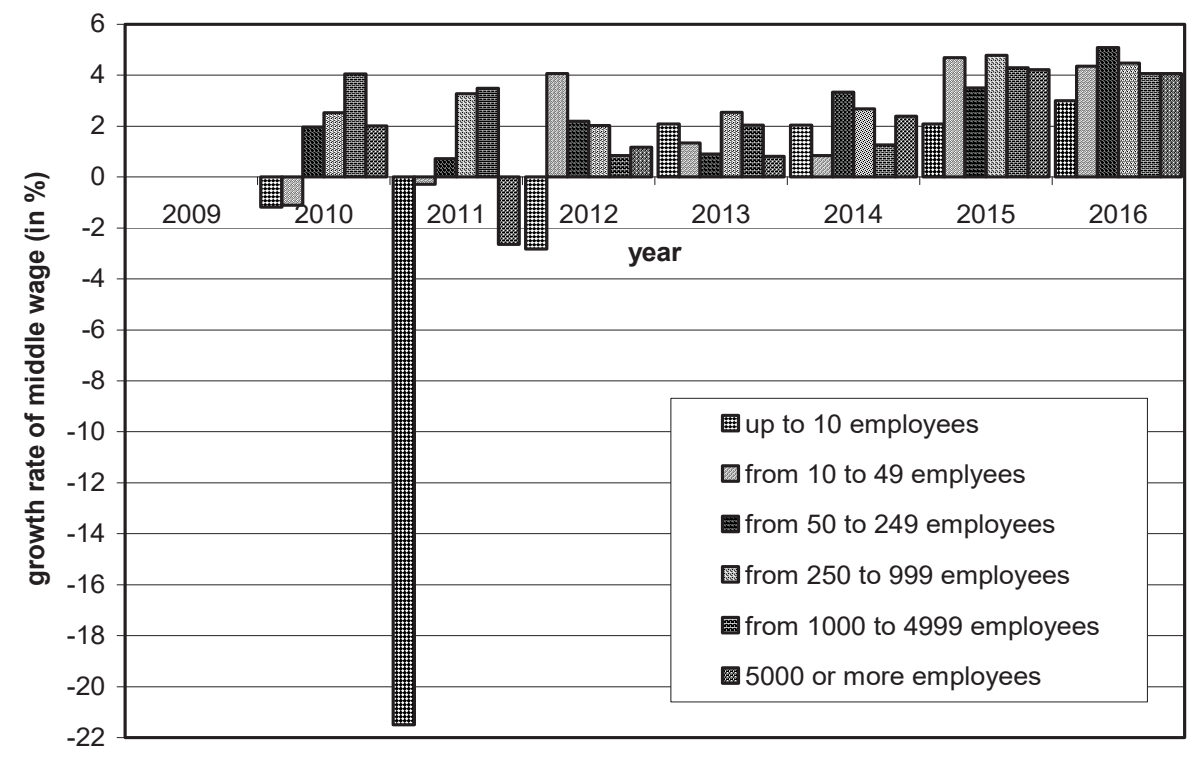

Source: Author's own research

Figures 9-12 (see the appendix) provide a comparison of the shapes of the wage distribution between the smallest and the largest enterprises in different years - after the onset of the recession (2009), when it adversely affected the Czech Republic (2011), in its aftermath (2014) and in the last year of the monitored period (2016). For post-crisis periods (Figures 11 and 12 in the Appendix), the scale on the vertical axis had to be 
changed due to better readability because the wage distributions for both the smallest and the largest companies exhibit much less kurtosis than during the recession.

Using the obtained lognormal curves, the proportions of employees receiving certain wages were calculated; see Table 4 . For example, $47.72 \%$ of employees in micro-enterprises earn a gross monthly wage less than $15,000 \mathrm{CZK}$, compared to just $1 \%$ in large and $1.55 \%$ in very large enterprises. Currently, the average gross monthly wage is slightly exceeding 30,000 CZK. Table 4 indicates that $91.4 \%$ of employees in the smallest firms do not achieve the average wage, whereas in large and very large companies this share is estimated at $47.10 \%$ and $51.56 \%$, respectively. It is also noticeable that only about $1 \%$ of micro-enterprise employees are paid more than $60,000 \mathrm{CZK}$ gross per month, while in large and very large firms nearly $8 \%$ and $7 \%$ of employees, respectively, are above this threshold value.

Table 3 | Development of variability characteristics (standard deviation in CZK and coefficient of variation in \%) and Gini coefficient of diversification (in \%)

\begin{tabular}{|c|c|c|c|c|c|c|c|}
\hline \multirow{2}{*}{ Characteristic } & \multirow{2}{*}{ Year } & \multicolumn{6}{|c|}{ Company size (No. of employees) } \\
\hline & & $1-9$ & $10-49$ & $50-249$ & $250-999$ & $1,000-4,999$ & $5,000+$ \\
\hline \multirow{8}{*}{$\begin{array}{l}\text { Standard } \\
\text { deviation }\end{array}$} & 2009 & 9,265 & 14,297 & 14,279 & 14,837 & 15,631 & 14,570 \\
\hline & 2010 & 9,006 & 14,139 & 14,402 & 14,955 & 15,572 & 15,181 \\
\hline & 2011 & 11,325 & 13,761 & 14,603 & 15,297 & 15,854 & 15,277 \\
\hline & 2012 & 9,077 & 14,055 & 14,815 & 15,437 & 15,956 & 15,485 \\
\hline & 2013 & 9,017 & 13,967 & 14,891 & 15,664 & 16,390 & 15,697 \\
\hline & 2014 & 8,942 & 14,358 & 14,963 & 15,838 & 16,486 & 15,656 \\
\hline & 2015 & 9,675 & 14,881 & 15,198 & 16,145 & 16,790 & 16,222 \\
\hline & 2016 & 10,613 & 15,129 & 15,580 & 16,349 & 16,917 & 16,475 \\
\hline \multirow{8}{*}{$\begin{array}{l}\text { Coefficient } \\
\text { of variation }\end{array}$} & 2009 & 46.70 & 58.34 & 55.26 & 55.48 & 53.07 & 49.46 \\
\hline & 2010 & 45.51 & 59.14 & 55.40 & 55.16 & 51.80 & 49.98 \\
\hline & 2011 & 64.54 & 59.08 & 55.97 & 54.50 & 51.13 & 50.41 \\
\hline & 2012 & 55.02 & 58.36 & 55.40 & 53.61 & 50.76 & 49.48 \\
\hline & 2013 & 53.94 & 57.62 & 55.62 & 53.30 & 51.44 & 50.55 \\
\hline & 2014 & 52.90 & 58.07 & 54.37 & 52.90 & 51.00 & 49.70 \\
\hline & 2015 & 55.05 & 57.69 & 53.50 & 51.70 & 49.69 & 49.93 \\
\hline & 2016 & 57.45 & 56.54 & 52.46 & 49.91 & 48.09 & 48.83 \\
\hline \multirow{8}{*}{$\begin{array}{l}\text { Gini } \\
\text { coefficient }\end{array}$} & 2009 & 22.38 & 27.16 & 26.32 & 26.50 & 25.89 & 24.53 \\
\hline & 2010 & 21.94 & 27.31 & 26.38 & 26.43 & 25.47 & 24.79 \\
\hline & 2011 & 26.80 & 27.18 & 26.59 & 26.29 & 25.27 & 24.95 \\
\hline & 2012 & 23.84 & 27.09 & 26.47 & 26.04 & 25.16 & 24.65 \\
\hline & 2013 & 23.35 & 26.73 & 26.44 & 25.89 & 25.37 & 24.98 \\
\hline & 2014 & 22.95 & 26.86 & 26.02 & 25.72 & 25.19 & 24.64 \\
\hline & 2015 & 23.11 & 26.57 & 25.56 & 25.19 & 24.61 & 24.62 \\
\hline & 2016 & 23.41 & 26.03 & 25.10 & 24.46 & 23.92 & 24.12 \\
\hline
\end{tabular}

Source: Author's own research 
Table 4 | Share of employees with wage limits from 15,000 to 120,000 CZK (in \%) by company size (2016)

\begin{tabular}{|l|c|c|c|c|c|c|}
\hline \multirow{2}{*}{$\begin{array}{l}\text { Wage } \\
\text { limit }\end{array}$} & \multicolumn{6}{|c|}{ Company size (No. of employees) } \\
\cline { 2 - 7 } & $\mathbf{1 - 9}$ & $\mathbf{1 0 - 4 9}$ & $\mathbf{5 0 - 2 4 9}$ & $\mathbf{2 5 0 - 9 9 9}$ & $\mathbf{1 , 0 0 0 - 4 , 9 9 9}$ & $\mathbf{5 , 0 0 0 +}$ \\
\hline $\mathbf{1 5 , 0 0 0}$ & $\mathbf{4 7 . 7 2}$ & $\mathbf{1 2 . 0 7}$ & 5.41 & 2.21 & 1.00 & 1.55 \\
\hline $\mathbf{2 0 , 0 0 0}$ & $\mathbf{7 4 . 2 7}$ & $\mathbf{3 8 . 8 8}$ & $\mathbf{2 6 . 6 9}$ & 17.13 & 11.43 & 14.41 \\
\hline $\mathbf{3 0 , 0 0 0}$ & 91.40 & $\mathbf{7 3 . 0 1}$ & $\mathbf{6 4 . 4 0}$ & 54.84 & 47.10 & 51.56 \\
\hline $\mathbf{4 0 , 0 0 0}$ & 96.28 & 87.25 & 82.91 & 77.33 & 72.28 & 75.35 \\
\hline $\mathbf{5 0 , 0 0 0}$ & 98.13 & 93.47 & 91.37 & 88.41 & 85.60 & 87.38 \\
\hline $\mathbf{6 0 , 0 0 0}$ & 98.96 & 96.42 & 95.40 & 93.85 & 92.34 & 93.33 \\
\hline $\mathbf{7 0 , 0 0 0}$ & 99.38 & 97.92 & 97.42 & 96.60 & 95.80 & 96.35 \\
\hline $\mathbf{8 0 , 0 0 0}$ & 99.61 & 98.74 & 98.49 & 98.05 & 97.62 & 97.93 \\
\hline $\mathbf{9 0 , 0 0 0}$ & 99.74 & 99.21 & 99.09 & 98.85 & 98.61 & 98.78 \\
\hline $\mathbf{1 0 0 , 0 0 0}$ & 99.83 & 99.48 & 99.43 & 99.30 & 99.17 & 99.27 \\
\hline $\mathbf{1 1 0 , 0 0 0}$ & 99.88 & 99.66 & 99.63 & 99.56 & 99.49 & 99.55 \\
\hline $\mathbf{1 2 0 , 0 0 0}$ & 99.91 & 99.76 & 99.76 & 99.72 & 99.68 & 99.71 \\
\hline
\end{tabular}

Source: Author's own research

Overall, wage levels rise with increasing company size - employees in micro firms (less than 10 staff) earn the least, those working for large companies (between 1,000 and 4,999 employees) receive the most, very large enterprises (with more than 5,000 staff) paying slightly lower wages than the latter ones. Tables 5 and 6 serve to verify the dependence of the gross monthly wage on the employer size. The values of the test criterion in the former table clearly showed the statistical significance of dependence, see the latter one. Thus, it can be concluded that the gross monthly wage dependence on the establishment size is confirmed even at a $1 \%$ level of statistical significance. This may be due to the large sample sizes (see Table 5) and the corresponding power of the test allowing for the revelation of all insignificant deviations from independence. However, the dependence of the gross monthly wage on company size can be regarded as proven even at the $1 \%$ significance level. 
Table 5 | Analysis of variance

\begin{tabular}{|l|c|c|c|c|c|c|}
\hline Year & $\begin{array}{c}\text { Total } \\
\text { average }\end{array}$ & $\begin{array}{c}\text { Total } \\
\text { standard } \\
\text { deviation }\end{array}$ & $\begin{array}{c}\text { Average } \\
\text { of conditional } \\
\text { variance } \\
\text { (intragroup } \\
\text { variability) }\end{array}$ & $\begin{array}{c}\text { Variance } \\
\text { of conditional } \\
\text { averages } \\
\text { (intergroup } \\
\text { variability) }\end{array}$ & Sample size & $\begin{array}{c}\text { Statistical } \\
\text { significance }\end{array}$ \\
\hline $\mathbf{2 0 0 9}$ & 26,677 & 14,766 & $214,463,394$ & $3,566,167$ & $1,672,377$ & $* * *$ \\
\hline $\mathbf{2 0 1 0}$ & 26,881 & 14,912 & $217,084,872$ & $5,282,892$ & $1,683,891$ & $* * *$ \\
\hline $\mathbf{2 0 1 1}$ & 25,645 & 14,979 & $206,338,937$ & $18,019,373$ & $1,727,475$ & $* * *$ \\
\hline $\mathbf{2 0 1 2}$ & 26,033 & 15,058 & $203,556,169$ & $23,173,968$ & $3,502,598$ & $* * *$ \\
\hline $\mathbf{2 0 1 3}$ & 26,211 & 15,173 & $206,900,754$ & $23,330,020$ & $3,502,200$ & $* * *$ \\
\hline $\mathbf{2 0 1 4}$ & 26,802 & 15,351 & $211,968,465$ & $23,698,584$ & $3,513,000$ & $* * *$ \\
\hline $\mathbf{2 0 1 5}$ & 27,811 & 15,795 & $222,699,655$ & $26,785,960$ & $3,567,700$ & $* * 2,627,900$ \\
\hline $\mathbf{2 0 1 6}$ & 29,060 & 16,165 & $232,772,541$ & $28,536,954$ & 3,60 \\
\hline
\end{tabular}

Source: Author's own research

Note: * means significance level $0.10 ; * *$ means significance level 0.05 ;** means significance level 0.01

\section{Conclusion}

The size of the company may affect a jobseeker's final decision. The relative strengths of small firms, such as team cohesion and non-bureaucratic structure, do not, however, overcome the problem of the pay that often outweighs the potential benefits.

There are several reasons why different employers pay different wages. Trade unions, mostly operating in large enterprises, usually bargain more effectively than individual workers in smaller firms, establishing higher wage rates in collective agreements and securing regular pay rises. Large companies are also likely to negotiate better external conditions. Small companies, not having such economic power, make relatively lower business profits and try to reduce their labour costs. However, this depends on the industry. Lean production allows small IT firms, for example, to pay wages higher than those in much larger enterprises.

Small and medium companies form the major economic segment in the Czech Republic, representing about half of long-term employment contracts and a third of the national economic output. Prevailing in the above segment and increasing in numbers during the boom years, micro-enterprises with a maximum of 9 people (1.2 on average) report the lowest wage rates with the average wage not reaching three-quarters of those in the whole company sector. This relative wage difference was amplified by the global financial and economic crisis.

Diverse statistical findings for different years summarised in this paper confirm that small and middle-sized enterprises are strongly affected by changes over the economic cycle. Their fluctuating numbers are contradictory even in the booming economy. Despite 
many self-employed people winding up their businesses when larger employers attract more of the workforce with higher wages, a considerable proportion of the smallest firms continue to influence the dynamics of this business sector. The impact of company size on the wage rate has been statistically proven even at a one per cent level of significance.

In terms of earnings, current research shows that large enterprises are much more attractive to potential employees. Those working in small companies with up to 10 staff receive only $55 \%$ of the wage earned in enterprises with over 1,000 employees.

In general, the average wage increases with the growing size of the company, even after deducting management salaries. However, when comparing average wages in the same jobs between the smallest and largest companies, the CSO statistics indicate that many small firms pay higher wages; such job positions are, for example, those of a construction locksmith, window dresser, confectioner or crane operator. The reason is that many small enterprises operating in specialised fields thrive due to a combination of a personal approach and flexible working practices. In the given industry, they can thus afford to pay higher-than-average wages, not just in scarce skill jobs.

On the other hand, in large enterprises, relatively high pay is typical for managerial positions which carry greater personal responsibility and accountability for running the business. Moreover, the CSO figures show that other job positions in large companies are also on average better paid than the same ones in small firms; typical examples are design engineers and chief accountants.

Large organisations attract new staff not only by the prospect of higher pay; the career advancement they offer is important for $75 \%$ of Czech employees. However, new opportunities pose significant challenges for both executives and staff seeking job promotion or/and working in a multicultural environment. The necessary language skills and a willingness to travel or move for work are especially required by international corporations.

However, in the Czech Republic, small and medium enterprises are the key employers and recent data shows a current trend towards micro-enterprises with up to ten employees. Their greater adaptability allows a flexible customer-centric approach to the ever-changing market requirements and enables them to fill niches more swiftly than large firms. Moreover, employees of small businesses often experience greater job satisfaction and enjoy more freedom of independent decision-making with red tape being comparatively curbed.

Contextualising the issue internationally, business surveys conducted out by the World Bank, for example, represent a unique source of information covering developing countries in particular. An extensive research project was conducted by Yang (2013) who presented an analysis of more than 45,000 manufacturing and service companies from 106 countries in five regions worldwide. The study indicates that large enterprises with a hundred or more employees tend to be more productive, offer higher pay and provide more formal training programmes. The author shows that labour productivity and wages in large companies are on average three and two times, respectively, higher than in small firms, and about two-thirds of large organisations run formal training courses. Interestingly, the most striking differences between small and large companies are reported in SubSaharan Africa, similar levels of labour productivity are in Eastern Europe and Central Asia, and in some small-sized island economies, small firms pay higher wages than large ones. However, the overall results are relatively consistent across all regions. 


\section{References}

Allemand, T., Plasman, R., \& Rycx, F. (2007). The Establishment-Size Wage Premium: Evidence from European Countries. Empirica, 34(5), pp. 427-451.

https://doi.org/10.1007/s10663-007-9042-3

Barron, J. M., Black, D. A., \& Loewenstein, M. A. (1987). Employer Size: The Implications for Search, Training, Capital Investment, Starting Wages, and Wage Growth. Journal of Labor Economics, 5(1), pp. 76-89. https://doi.org/10.1086/298138

Brian, G. M., \& Reilly, B. (1993). The Employer Size-Wage Gap: Evidence for Britain. Economica, 60(238), pp. 125-142. https://doi.org/10.2307/2554585

Brown, C., \& Medoff, J. (1989). The Employer Size-Wage Effect. Journal of Political Economy, 97(5), pp. 1027-1059. https://doi.org/10.1086/261642

Brunelloa, G., \& Colussib, A. (1998). The Employer Size-Wage Effect: Evidence from Italy. Labour Economics, 5(2), pp. 217-230. https://doi.org/10.1016/S0927-5371(98)00006-2

Chotikapanich, D. (2008). Modeling Income Distributions and Lorenz Curves. New York, NY: Springer.

Dunne, T., \& Schmitz, J. A. (1995). Wages, Employment Structure and Employer Size-Wage Premia: Their Relationship to Advanced-Technology Usage at US Manufacturing Establishment. Economica, 62(245), pp. 89-107. https://doi.org/10.2307/2554777

Glantz, S., Slinker, B., \& Neilands, T. (2016). Primer of Applied Regression \& Analysis of Variance. New York, NY: McGraw-Hill.

Hartog, J., Opstal, R. Van., \& Teulings, C. N. (1997). Inter-Industry Wage Differentials and Tenure Effects in the Netherlands and the U. S. De Economist, 145(1), pp. 91-99. https://doi.org/10.1023/A:1002977129905

Hollister, M. N. (2004). Does Firm Size Matter Anymore? The New Economy and Firm Size Wage Effect. American Sociological Review, 69(5), pp. 659-679. https://doi.org/10.1177/000312240406900503

Johnson, N. L., Kotz, S., \& Balakrishnan, N. (1994). Continuous Univariate Distributions, Vol. 1 (2nd. ed.). New York, NY: Wiley-Interscience.

Johnson, N. L., Kotz, S., \& Balakrishnan, N. (1995). Continuous Univariate Distributions, Vol. 2. (2nd. ed.). New York, NY: Wiley-Interscience.

Kleiber, C., \& Kotz, S. (2003). Statistical Size Distributions in Economics and Actuarial Sciences. New York, NY: Wiley-Interscience.

Kruse, D. (1992). Supervision, Working Conditions, and the Employer Size-Wage Effect. Industrial Relations: A Journal of Economy and Society, 31(2), pp. 229-249. https://doi.org/10.1111/j.1468-232X.1992.tb00307.x

Larson, R., \& Farber, B. (2015). Elementary Statistics: Picturing the World. Edinburgh, UK: Pearson Education Limited.

Mellow, W. (1982). Employer Size and Wages. The Review of Economics and Statistics, 64(3), pp. 495-501. https://doi.org/10.2307/1925949

Reilly, K. T. (1995). Human Capital and Information: The Employer Size-Wage Effect. The Journal of Human Resources, 30(1), pp. 1-18. https://doi.org/10.2307/146188

Schmidt, C. M., \& Zimmermann, K. F. (1991). Work Characteristics, Firm Size and Wages. The Review of Economics and Statistics, 73(4), pp. 705-710. https://doi.org/10.2307/2109410 
Velenchik, A. D. (1997). Government Intervention, Efficiency Wages, and the Employer Size Wage Effect in Zimbabwe. Journal of Development Economics, 53(2), pp. 305-338. https://doi.org/10.1016/S0304-3878(97)00019-9

Yang, J. (2013). Large Firms Are More Productive, Offer Higher Wages and More Training [Report No. 82051, online]. The World Bank. Available at:

http://documents.worldbank.org/curated/en/651051467990379863/Large-firms-aremore-productive-offer-higher-wages-and-more-training [Accessed 24 Oct. 2013]

\section{Appendix}

Figure 3 | Development of theoretical model wage distribution for companies with less than 10 employees (2009-2016)

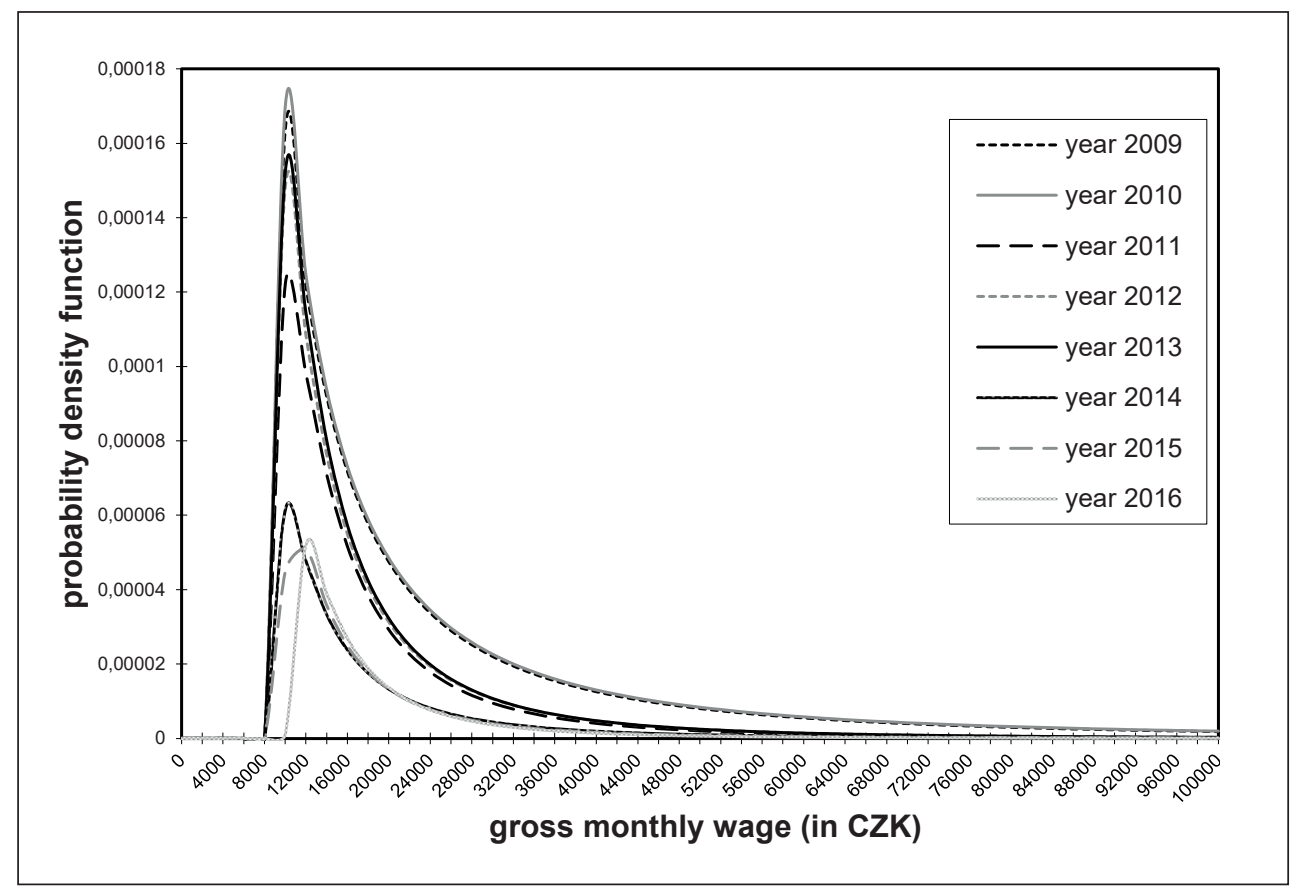

Source: Author's own research 
Figure 4 | Development of theoretical model wage distribution for companies with 10-49 employees (2009-2016)

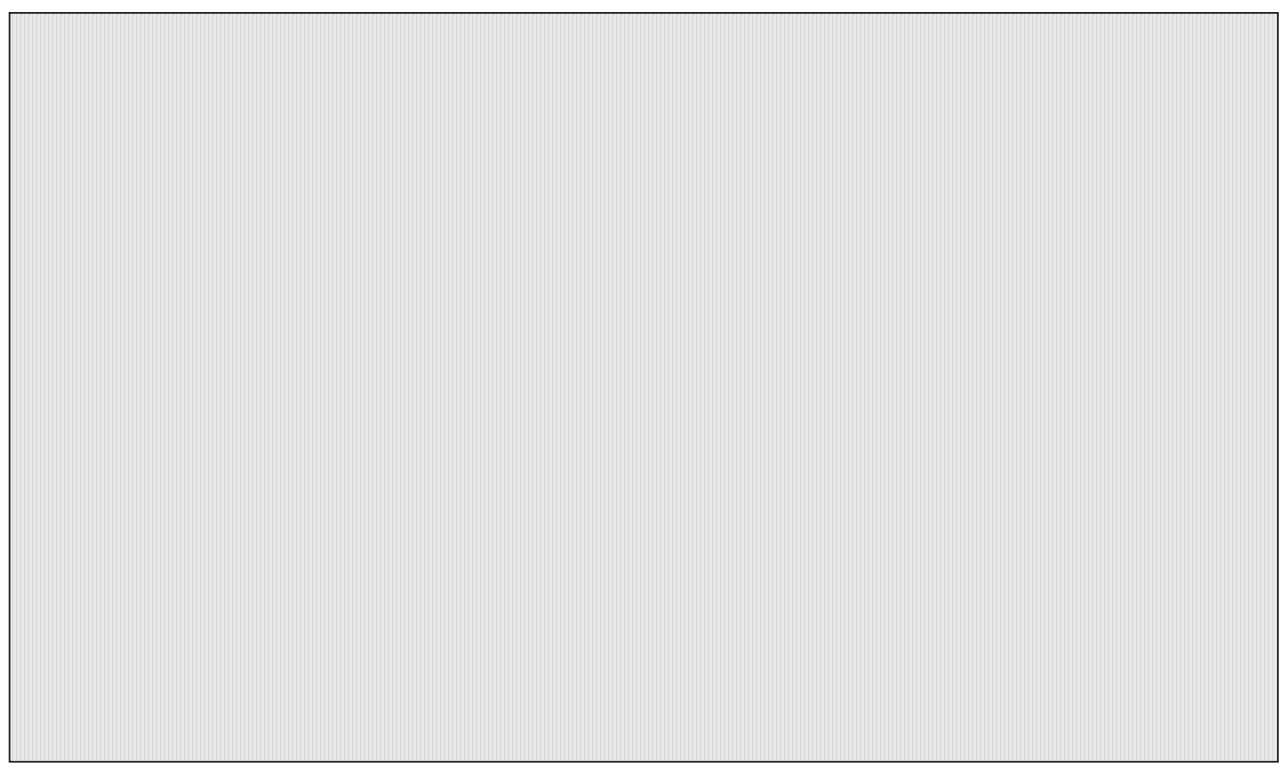

Source: Author's own research

Figure 5 | Development of theoretical model wage distribution for companies with 50-249 employees (2009-2016)

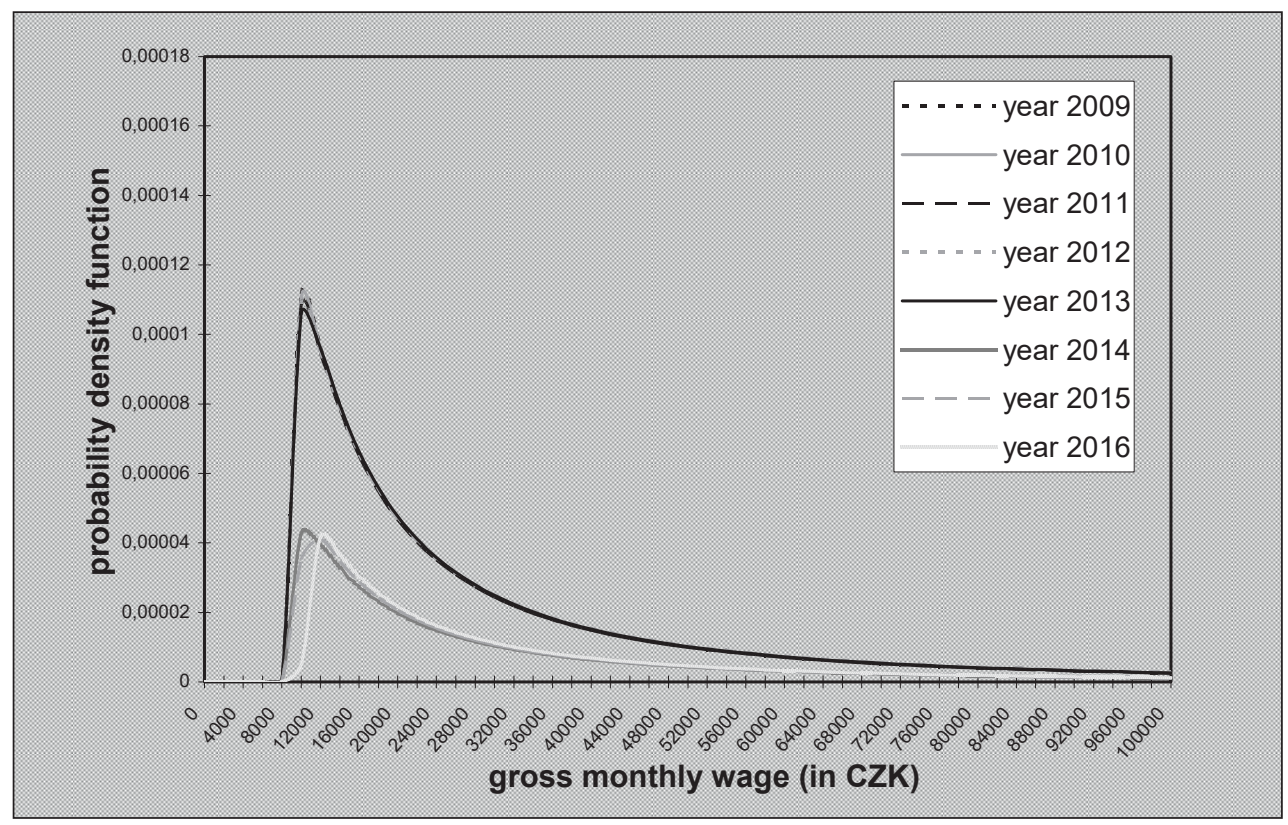

Source: Author's own research 
Figure 6 | Development of theoretical model wage distribution for companies with 250-999 employees (2009-2016)

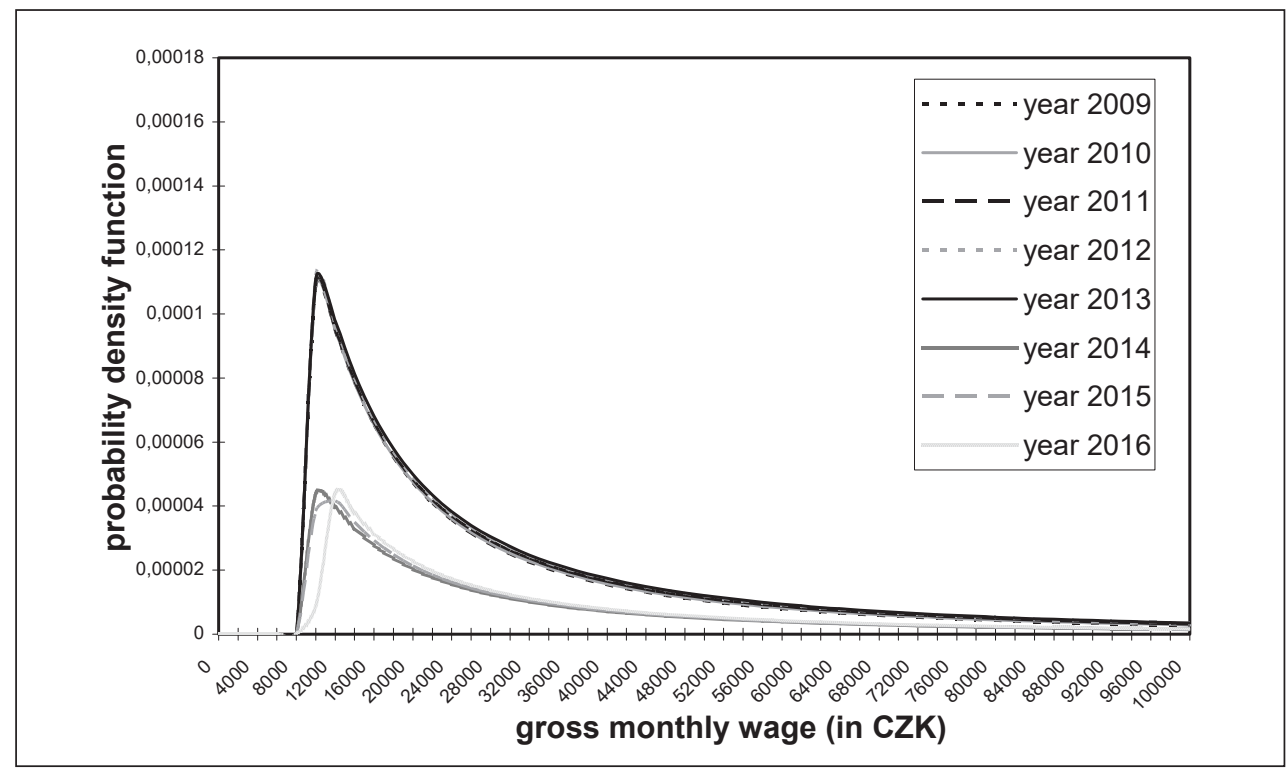

Source: Author's own research

Figure 7 | Development of theoretical model wage distribution for companies with 1,000 - 4,999 employees (2009-2016)

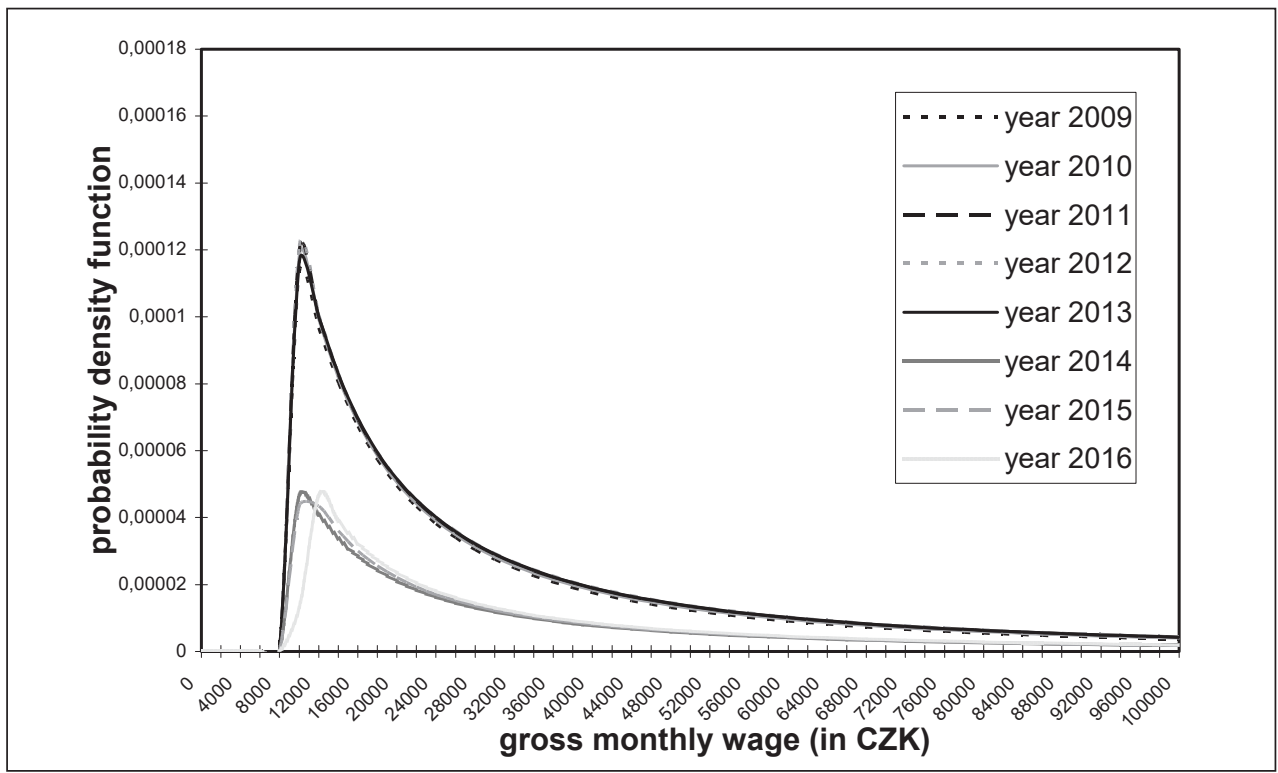

Source: Author's own research 
Figure 8 | Development of theoretical model wage distribution for companies with 5,000 or more employees (2009-2016)

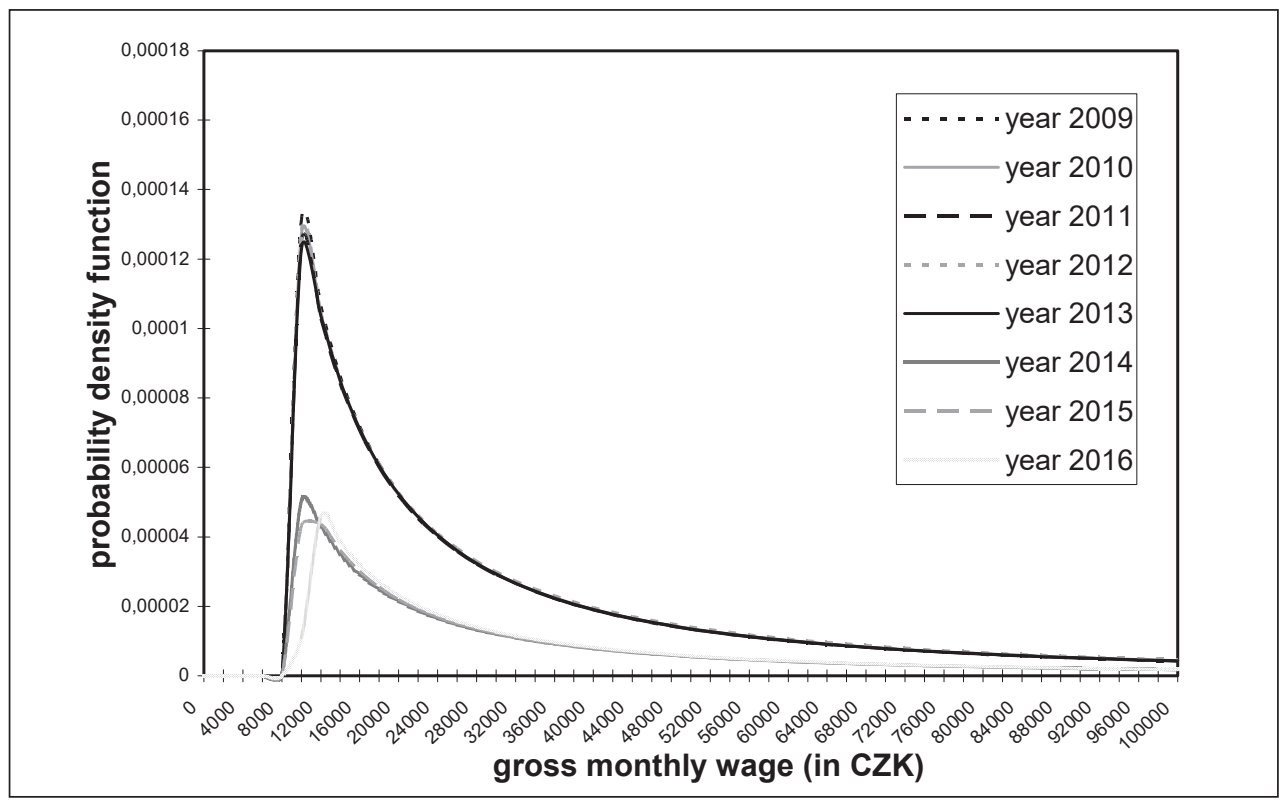

Source: Author's own research

Figure 9 | Model wage distribution for the smallest and the largest companies (2009)

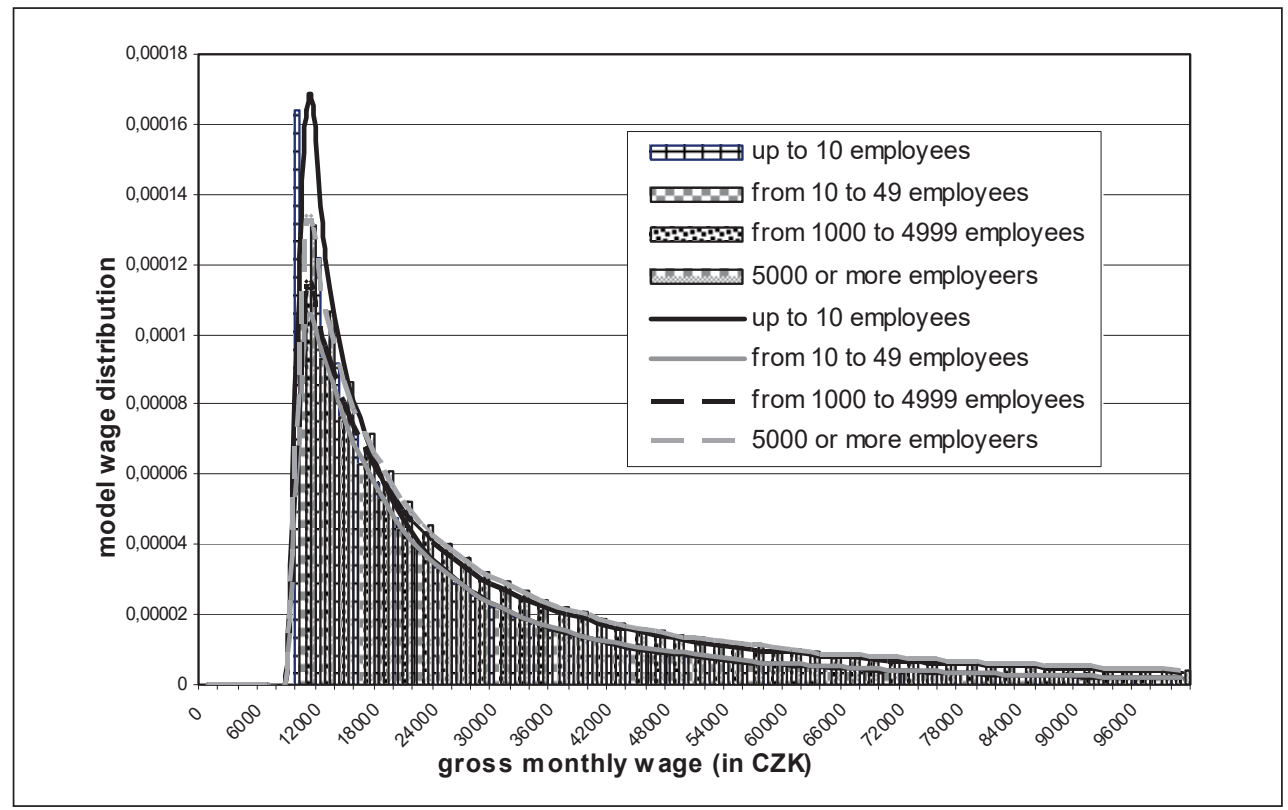

Source: Author's own research 
Figure 10 | Model wage distribution for the smallest and the largest companies (2011)

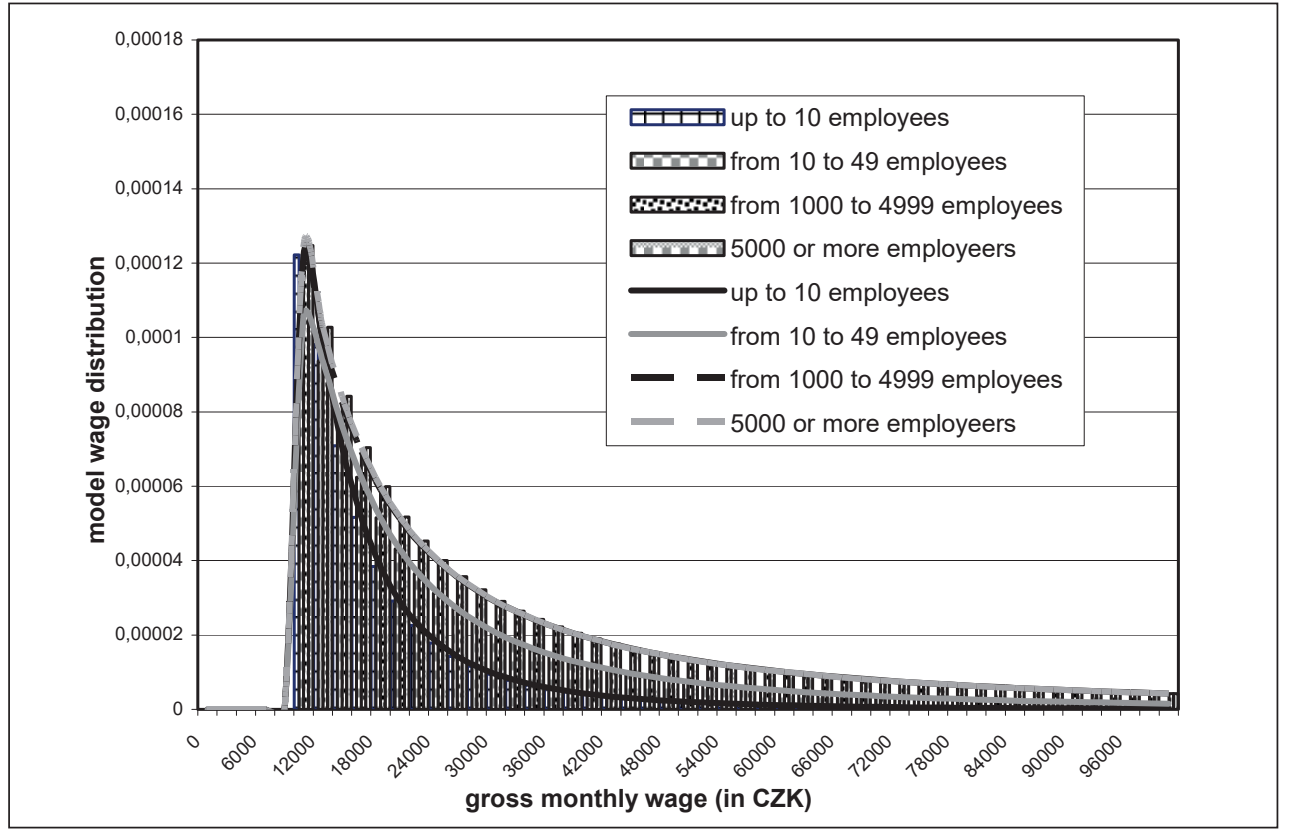

Source: Author's own research

Figure 11 | Model wage distribution for the smallest and the largest companies (2014)



Source: Author's own research 
Figure 12 | Model wage distribution for the smallest and the largest companies (2016)

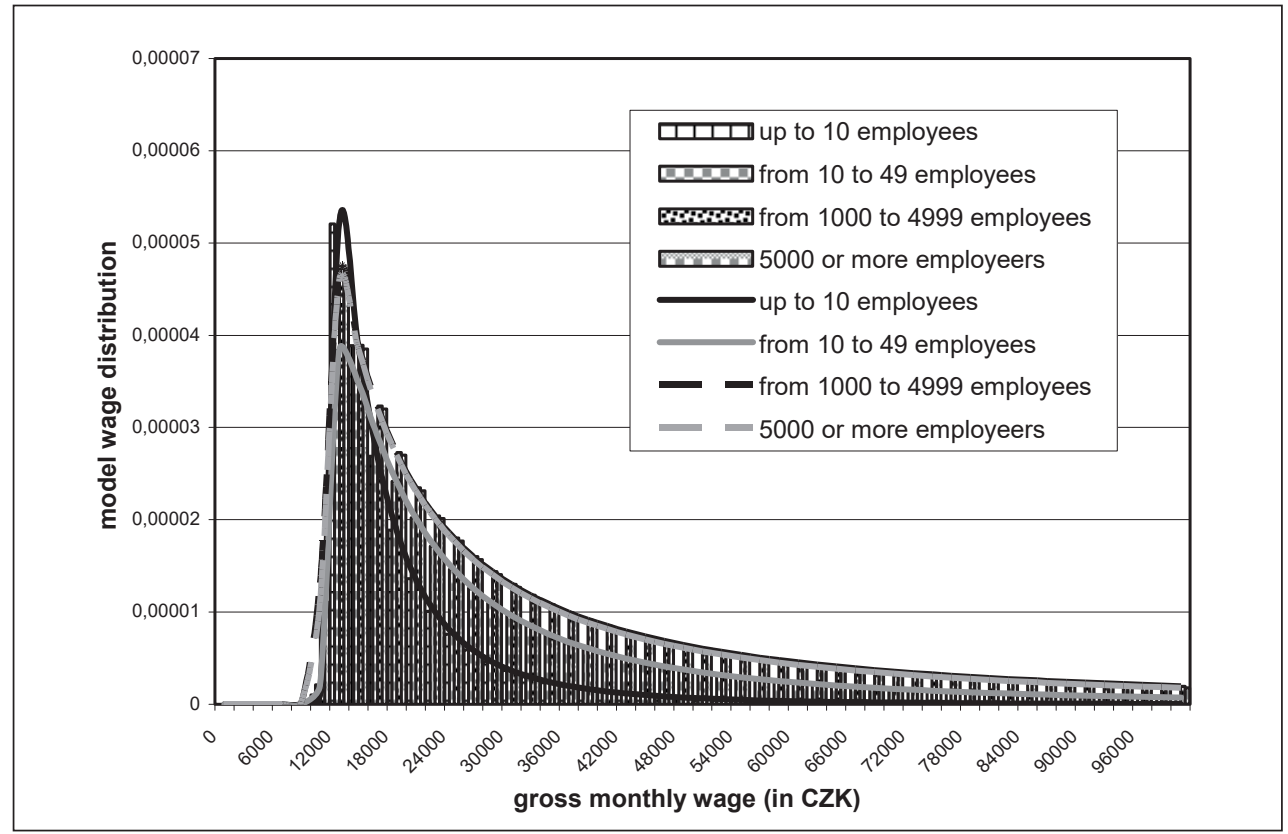

Source: Author's own research 